\title{
Ethnocentrism in Polish Consumer Food Behaviour as a Determinant of Short Supply Chain Development
}

\author{
By Gabriela Hanus ${ }^{1}$
}

\begin{abstract}
The main purpose of this research is to investigate the phenomenon of ethnocentrism in the food behaviour of Poles as a possible determinant of the development of short supply chains. For this purpose, primary and secondary tests were carried out. The primary studies examine the level of ethnocentrism in the food behaviour of Poles, while secondary data analysis focuses on finding a relation between this phenomenon and the development of short supply chains. The primary source of the survey consists in the results of an online and distributed survey covering the whole of Poland. A total of 660 people took part in the study. The main secondary sources used in the work include the latest publications in peer-reviewed scientific journals. Across the studies covered by this paper it was found that ethnocentrism is clearly observable in the food behaviours of Poles and it might have significant influence on the development of short supply chains.
\end{abstract}

Keywords: ethnocentrism; short supply chain; food behaviour

\section{Introduction}

After years of saturation with economic and social freedoms, openness to Western novelties, as well as increasing consumer nutritional awareness and many social campaigns, Polish consumers are uncertain about the quality and health value of food produced on a mass scale by multinational corporations. Local, high-quality products manufactured by indigenous producers and sold in close proximity to the production units began to enjoy greater confidence. Thus, two phenomena can be observed in the eating behaviour of Polish consumers: ethnocentrism and increased interest in short supply chains. Both have been the subject of many research projects and programmes; however, the connection between ethnocentrism in consumer food behaviour and the development of short supply chains in the Polish food market has not been made by many authors. Therefore, the main purpose of this paper is to identify and characterise the phenomenon of ethnocentrism in the food behaviour of Polish consumers, the factors shaping it and its link with short supply chain development in the Polish food market. The following hypothesis is drawn: increasing levels of ethnocentrism in consumer food behaviour may be presumed to increase interest in food supplied through short supply chains. The scope of the primary research concerns individual consumers who independently decide about their diet (over 18 years of age). Direct research was conducted in the third quarter of 2018 and covered the entire territory of Poland.

It should be noted that research conducted so far has some restrictions. First of all, the studies carried out are non-exhaustive; thus, it is not possible to generalise them for the entire population. Secondly, the research method involved a questionnaire, which is not 
without flaws, such as superficiality and limited possibilities of delving deeper into the subject.

The paper is divided into the following sections. The first presents ethnocentrism and short supply chains in theoretical terms. The second is dedicated to the methodology and data collection, while the third presents the empirical results of the research and a discussion. The conclusion provides a summary and indicates the applicability of the work and further research directions.

\section{Literature Review}

\subsection{Ethnocentrism in theoretical terms}

In the twenty-first century, factors related to consumer attitudes and awareness towards local or regional brands and products, as well as the economic operators involved in their production and sale, are becoming increasingly important. This is an expression of the emergence of ethnocentric phenomena. The concept of ethnocentrism was introduced as early as 1906 by the American ethnologist and sociologist W.G. Sumner, who defined it as the perception of things, people or behaviours and their comparison and evaluation from the point of view of one's environment. This attitude leads to the perception of one's own group as the centre, while all others are judged and classified in relation to that group. An inherent element of ethnocentrism is, therefore, the tendency to affirm one's own culture, while at the same time depreciating foreign cultures. The full adaptation of ethnocentrism to market relations was carried out in 1987 by T.A. Shimp and S. Sharma, who defined it as the belief that buying products of domestic origin is a moral obligation, while buying imported goods is inappropriate due to the negative impact on the economy and employment (Kavak et al., 2007). This is why ethnocentrism is now most often seen as a preference for products of national origin, as well as providing individuals with a sense of their own identity and belonging to a particular group. In consumer diets, this trend is reflected mainly in the preference for foods of local origin (Sajdakowska, 2003). On the basis of studies carried out in Finland, Autio et al. have shown that Finnish residents are willing to pay more for food they can buy directly from a farmer at a maximum distance of $80 \mathrm{~km}$ from their place of residence. In addition, some of them set up their own small-scale vegetable and fruit production in their garden, balcony or allotment (Autio et al., 2013). In contrast, studies by $G$. Chryssochoidis et al. have shown that ethnocentrism affects not only consumer beliefs but also the way in which the perceived quality of domestic and foreign products is assessed (Chryssochoidis et al., 2007).

Among the determinants of ethnocentric attitudes are sociodemographic, economic and psychological consumer characteristics such as age, education and wealth. It has been noted that younger consumers with higher education and above-average wealth levels are more likely to have an internationalist attitude, i.e. opposite to an ethnocentric one. What is more, women generally rate foreign products higher than men. Conversely, it has been shown that people living in regions threatened by unemployment or job losses are more inclined to buy products of domestic origin or with labels emphasising the Polish origin of food. There is also a link between ethnocentric behaviour and the level of economic development of the country. In countries with a lower level of development, consumers 
have a worse opinion of domestic products, while in highly industrialised countries, domestic products are considered to be of higher quality. Other factors determining ethnocentric attitudes include openness to foreign culture, patriotism, as well as relations between collective and individual values. Germany and the United Kingdom are examples of countries with national traditions and a high level of development, where there is a clear consumer preference for domestic products. Another factor may be the type of product and, especially, the diversity of products in a given group. It has been shown that homogeneous products are treated as identical, regardless of producer. The brand or country of origin of a product is more important for differentiated goods. It should be noted, however, that consumers are not always aware of the country of origin of brands, often confusing Polish with foreign ones (Sajdakowska, 2003).

The theoretical antecedents of consumer ethnocentricity and its effect on attitudes towards importing products can be found in the following authors, such as T.A. Shimp, S. Sharma, J. Shin, D.M. Taylor and V. Jaggi, J.J. Watson, K. Wright, M.N. Shankarmahesh, G. Balabanis, and A. Diamantopoulos (Shimp et al., 1987; Sharma et al., 1994; Taylor et al., 1974; Watson et al., 2000; Shankarmahesh, 2006, Balabanis et al., 2004). In Poland, such research was conducted for example in 1994-1995 by A. Falkowski and B. Falkowski. It showed that younger people, with higher incomes and lower education, living in small towns and cities were characterised by a lower level of ethnocentrism than others (Włodarczyk, 2015). The results were also confirmed by two surveys, one carried out in 2006 by K. Zięba and S. Ertmanski (Zięba et al., 2006), and one in 2014 by A. Szromnik and E. Wolanin-Jarosz (Szromnik et al., 2014). It is also worth noting a research conducted in 2002 by the Department of Marketing and Services of the University of Economics in Katowice, which showed that consumers chose foreign products more often than Polish ones, but this concerned mainly household appliances and audio/video devices, cosmetics and sporting goods. In the case of food products, such as dairy products, sweets and alcoholic beverages, however, they demonstrated ethnocentric tendencies (Szromnik et al., 2013).

\subsection{Short supply chain - theoretical approach}

The short food supply chain (SFSC) is a significant issue for regional, as well as international, agro-food systems and has been widely discussed in the literature (D’Amico, Di Vita, Chinnici, Pappalardo, Pecorino and Canfora, 2016; Marsden, Banks and Bristow, 2000). A short supply chain is defined as 'a supply chain involving a limited number of economic operators, committed to co-operation, local economic development, and close geographical and social relations between producers, processors and consumers' (European rural development regulation 1305/2013, EIP-AGRI Focus Group, 2015). The term "short SFSC distances" means smaller distances compared to traditional supply chains, and refers to the transport distances covered by the product from the place of manufacture to the point of sale. This distance also includes the places of production of other elements used in agriculture, such as feed and pesticides. Social proximity, to the contrary, means the relationships and interactions between the participants in the exchange. This enables coordination, rapid flow of information between producers and consumers, as well as sharing the risks and benefits of production (Tundys, 2015; Coley et al., 2011; Pretty et al., 2005; Kawecka and 
Gębarowski, 2015). Therefore, short supply chains are also an expression of attempts by producers and consumers to adapt to new types of supply and demand (Marsden, Banks and Bristow, 2000).

Kawecka and Gębarowski (2015) note that in a short supply chain there is, at maximum, one intermediary between the producer and the end consumer. In other words, a short supply chain means a reduction in the number of intermediaries that are necessary to deliver the end product to the consumer. The role of transparency in the structure of the short food supply chain is emphasised, which means that all actors in the chain can easily be identified. Tundys (2015) additionally found that the construction of short supply chains is often based on traditional links and customs, which do not concern global supply chains. This achieves the basic objective of short supply chains, namely to strengthen local food networks, with strong involvement of both producers and consumers. Producers can, thus, regain an active role in the value creation of such a chain and the product itself (Tundys, 2015).

Moreover, a key characteristic of short supply chains is the ability to assess the relative suitability of food based on consumer knowledge or experience. Typically, such food is determined either by its location or even by the specific farm in which it is produced, and serves to exploit and improve the image of the farm and/or region as a source of quality food. It has, therefore, become extremely important to place clear indications of the origin of the food product (Marsden, Banks and Bristow, 2000).

It should be noted, however, that SFSCs are not only considered as a tool for improving farm incomes but also as a way for restructuring the food supply chain in order to support sustained and healthy farming methods, generate adequate means of subsistence for farms (in rural, suburban and urban areas) and relocate control over food management. Shortening the supply chain can have some positive environmental, economic and social impacts (EIP-AGRI Focus Group, 2015).

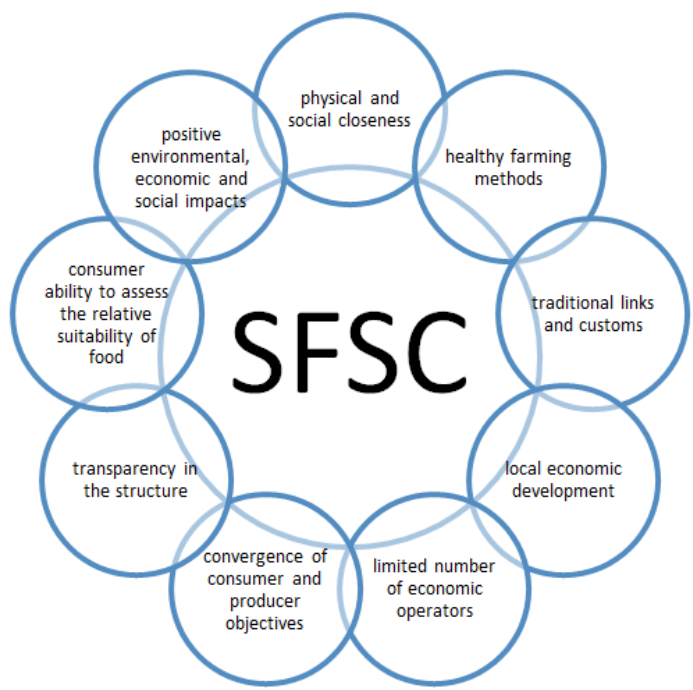

Fig. 1: The main characteristics of the short food supply chain.

Source: own study based on secondary sources 
Short supply chains may also be described in relation to sales methods, and production and distribution links. These solutions serve to maintain a short distance and number of intermediaries between producers and consumers. Authors distinguish three types based on number of intermediaries, physical distance and organisational links (Tundys, 2015; Renting et al., 2003; Galli and Brunori, 2013; Marsden, Banks and Bristow, 2000):

1) Face-to-face: the simplest and most direct type of SFSC, where the consumer purchases the product directly from the manufacturer/producer. This is made as a direct sale by natural persons on farms, as well as at a market, and by delivery to a house or a specific unit (e.g. a restaurant). Also, on the Internet it is now possible to make face-toface contact through online trading websites, which makes it possible to extend the geographical scope of product sales and direct links. The basis for this form of sales is authenticity and trust.

2) Spatial proximity: products are not sold directly, but are produced and sold in a specific production region (or location) and consumers are informed about the "local" nature of the product at the retail outlet. Examples are grocery stores, hotels, café restaurants, specialised retailers, as well as communities supporting agriculture. An important issue is the close relationship between producers and local intermediaries (e.g. restaurants, which use local products, especially those that work in accordance with the slow food movement).

3) Spatially extended: comprehensive information on food producers and the place of production is important for consumers who are outside the region of production itself and who have no personal experience of it. This means that products are sold to consumers located outside the region of production, who do not have direct and personal contact with the producers. Examples are Parmesan cheese (Parmigiano Reggiano) and fair-trade products (e.g. coffee, tea). In this case, the information accompanying the product, i.e. data about the place of production, rules, certificates, and not physical distance, is extremely valuable. It is on this basis that the customer decides to purchase certain goods.

\section{Data and Methodology}

In order to achieve the objectives of this article and verify the hypothesis adopted, it was necessary to conduct primary and secondary research of a quantitative nature. Primary research focused on the identification of the phenomenon of ethnocentrism ${ }^{1}$ in Polish consumer food behaviour and the factors shaping it, while secondary research concerned both the phenomenon of ethnocentrism, as well as the short food supply chain.

Individual consumers independently deciding on their diet (over 18 years of age) took part in direct research using quantitative methods. The research was conducted in 2018 across Poland. The measurement tool in the primary research was a questionnaire, which consisted of an introduction, instructions for the respondents, ten relevant questions and

\footnotetext{
${ }^{1}$ It should be noted that, other than ethnocentrism, the research conducted was intended to identify other trends in the food behaviour of Polish consumers; however, this paper focuses only on ethnocentrism in order to realise its objectives and hypothesis.
} 
five questions about demographic items.

Table 1. Characteristics of consumers participating in the survey $(n=660)$

\begin{tabular}{|c|c|c|}
\hline \multirow{2}{*}{ Characteristics of respondents } & \multicolumn{2}{|c|}{ Responses } \\
\hline & Number & $\%$ \\
\hline \multicolumn{3}{|l|}{ Gender } \\
\hline Female & 393 & $59.50 \%$ \\
\hline Male & 267 & $40.50 \%$ \\
\hline \multicolumn{3}{|l|}{ Age } \\
\hline $18-24$ & 103 & $15.6 \%$ \\
\hline $25-34$ & 166 & $25.2 \%$ \\
\hline $35-44$ & 102 & $15.5 \%$ \\
\hline $45-54$ & 84 & $12.7 \%$ \\
\hline $55-59$ & 50 & $7.6 \%$ \\
\hline $60-64$ & 50 & $7.6 \%$ \\
\hline 65 years or above & 105 & $15.9 \%$ \\
\hline \multicolumn{3}{|l|}{ Education } \\
\hline Basic & 6 & $0.9 \%$ \\
\hline Junior High School & 9 & $1.4 \%$ \\
\hline Professional & 233 & $35.3 \%$ \\
\hline Average & 327 & $49.5 \%$ \\
\hline Higher & 85 & $12.9 \%$ \\
\hline \multicolumn{3}{|l|}{ Income situation } \\
\hline Very bad & 13 & $2.0 \%$ \\
\hline $\mathrm{Bad}$ & 8 & $1.2 \%$ \\
\hline Average & 104 & $15.8 \%$ \\
\hline Okay & 235 & $35.6 \%$ \\
\hline Very good & 300 & $45.5 \%$ \\
\hline \multicolumn{3}{|l|}{ Place of residence } \\
\hline City & 407 & $61.7 \%$ \\
\hline Village & 253 & $38.3 \%$ \\
\hline
\end{tabular}

Source: own elaboration based on primary research results.

In online and distributed surveys covering the whole of Poland, a total of 660 people took part, including 393 women $(59.5 \%)$ and 267 men (40.5\%). People aged 18-34 constituted about $42 \%$ of those surveyed, people aged $35-5428 \%$, and people aged over $55,31 \%$ of those surveyed. The structure of the sample in terms of age and gender resulted from the quota selection, which reflected the structure of the population in Poland as of 31.12.2016. Other characteristics of the research sample included: education, income situation and place of residence. Almost half of the respondents had received secondary education $(49.5 \%)$, over $1 / 3$ had vocational training $(35.3 \%)$, and every seventh person had received higher education. Only $2.3 \%$ of respondents declared primary or lower secondary education (Table 1).

In order to examine the degree of occurrence of ethnocentrism as a new trend in Poles' eating behaviour, variables were operationalised. Table 2 presents how the phenomenon was measured. For data analysis, some statistical methods were used. A factor analysis 
and Cronbach's alpha were used as a measure for the reliability of measurement scales describing consumer behaviour. In order to study the relationship between consumer behaviour and consumer characteristics multiple regression models, Pearson's $\chi^{2}$ and Cramer's V coefficients were used. Moreover, some descriptive statistics and structure indicators for single questions were also determined.

Table 2. Operationalisation and measurement of variables

\begin{tabular}{|l|l|c|}
\hline $\begin{array}{l}\text { Studied } \\
\text { phenomenon }\end{array}$ & $\begin{array}{l}\text { Scale position } \\
\text { (questions) } *\end{array}$ & $\begin{array}{c}\text { Cronbach's alpha } \\
\text { for the scale }\end{array}$ \\
\hline \multirow{5}{*}{ Ethnocentrism } & $\begin{array}{l}\text { Purchase of food produced in Poland or from a local } \\
\text { supplier (4f) }\end{array}$ & Alfa $=0.676^{* *}$ \\
\cline { 2 - 2 } & $\begin{array}{l}\text { Choosing products produced by Polish food producers (5b) } \\
\text { Buying food from a proven source, e.g. a local grower (5c) }\end{array}$ & \\
\cline { 2 - 3 } & $\begin{array}{l}\text { Prefer shopping in small local grocery stores over large } \\
\text { supermarkets (5d) }\end{array}$ & \\
\hline
\end{tabular}

Source: own elaboration based on primary research results.

\section{Results and Discussion}

The analyses carried out showed that ethnocentrism is clearly visible in the nutritional behaviour of Polish consumers. The average of the assessments of behaviours closely related to the selected trend was about 3 or more on a 5 -grade scale (Table 3 ).

Table 3. Descriptive statistics for the phenomenon of ethnocentrism in the nutritional behaviours of Poles*

\begin{tabular}{|l|c|c|}
\hline Phenomenon & Average & Standard deviation \\
\hline Ethnocentrism & 4.01 & 0.98 \\
\hline * Intensity scales from 1 to 5 were used in the questions, and the ends of these scales were described differently, \\
depending on the question asked. Source: own elaboration based on primary research results.
\end{tabular}

Ethnocentric attitudes among older consumers may be due to the fact that they are more conservative and patriotic than younger consumers. The phenomenon of ethnocentrism in Polish consumers' food behaviour manifests itself in the preference of Polish food products and their purchase from local shops at least several times per month by $77 \%$ of respondents (Table 5).

Ethnocentrism is observed in the dietary behaviour of Poles, especially among those aged 60-64, who have an average ethnocentrism level 0.270 higher than that of people aged 18-24. Moreover, these are more often people with vocational training than lower secondary education, whose ethnocentrism level is on average 0.605 lower than that of people with vocational training (Table 6).

A number of surveys conducted among European (including Polish) consumers also indicates a high or moderate interest for regional and local food products (Karner, 2010; Żakowska-Biemans, 2012; Chudy and Gierałtowska, 2013; Annunziata and Scarpato, 2014; Gradziuk, 2015). According to the Opinion of the Committee of the Regions on "Local Food Systems" (Outlook Opinion, 2011), local food products:

- are manufactured locally/regionally; 
- have positive influence on local/regional rural development;

- are sold to the consumer through the shortest, most rational and efficient way, which consists of no more than the producer or local organisation, an entity or cooperative of entities responsible for matching supply and demand, and a consumer;

- might be sold in a local retail shop or market square on the basis of a local contract, but may not be sold - with the Local Food Label - to a central retail outlet;

- are characterised by one or more unique features, such as taste, high quality, freshness local tradition, cultural background, local speciality, environmental value, animal welfare, sustainable production conditions and health aspects;

- are sold as close as possible to the consumer, in the most rational and efficient way. The distance may vary per product, region and other circumstances, but there is one fundamental prerequisite, namely that the point of sale is the closest to the consumer (this distance may vary from $1 \mathrm{~km}$ to over $50 \mathrm{~km}$ ).

This attitude is in line with the assumptions of short supply chains, whose regional extent, producer-consumer partnerships, and sales through local sale points are particularly emphasised.

Other direct research also shows that consumers declaring their dietary choices as being in line with the "you are what you eat" principle exhibit an average of 0.278 higher levels of ethnocentrism than others. Also, those who pay more attention to the quality, composition and packaging of food have a higher level of ethnocentrism than those who do not. The increase in quality by 1 is accompanied by an increase in ethnocentrism by 0.233 , the increase in composition by 1 , entails an increase in ethnocentrism by 0.173 , and the increase in packaging by 1 is accompanied by an increase in ethnocentrism by 0.071. It is also worth noting that those who are interested in researching proper nutrition also show a higher level of ethnocentrism than others (on average 0.179). Conversely, consumers who used dietary supplements advertised in the media in the past year showed an average 0.263 lower level of ethnocentrism than others, which may result from purchasing these supplements from international corporations (Table 6). In other words, research has indicated that ethnocentric attitudes towards food products concern mainly those who appreciate the quality and good composition of products, have a higher nutritional awareness, and constantly improve their nutritional knowledge.

Table 5. Frequency of purchasing local food by Poles

\begin{tabular}{|l|c|}
\hline Frequency & Percentage of Responses \\
\hline Never & $2 \%$ \\
\hline Occasionally, in an emergency & $8 \%$ \\
\hline Several times a year & $13 \%$ \\
\hline Several times a month & $42 \%$ \\
\hline A few times a week & $35 \%$ \\
\hline
\end{tabular}

Source: own elaboration based on direct research. 
Table 5. Results of estimation of multiple regression models for ethnocentrism

\begin{tabular}{|c|c|c|}
\hline \multirow[t]{2}{*}{ Questions in questionnaire } & \multicolumn{2}{|c|}{ Ethnocentrism } \\
\hline & $\mathrm{b}$ & std(b) \\
\hline $\begin{array}{l}\text { According to the "you are what you eat" principle, do you pay attention to } \\
\text { what food products you choose? }\end{array}$ & 0.278 & $0.133^{* *}$ \\
\hline What does packaging mean for you when choosing a food product? & 0.071 & $0.036^{* *}$ \\
\hline What does price mean for you when choosing a food product? & -0.036 & 0.044 \\
\hline What does the company mean for you when choosing a food product? & 0.011 & 0.038 \\
\hline What does the quality mean for you when choosing a food product? & 0.233 & $0.076^{* * *}$ \\
\hline What does the caloric content mean for you when choosing a food product? & -0.045 & 0.038 \\
\hline What does composition mean for you when choosing a food product? & 0.173 & $0.059 * * *$ \\
\hline Do you think you are eating healthily? & 0.033 & 0.088 \\
\hline Do you use any diet (e.g. vegetable and fruit)? & 0.000 & 0.098 \\
\hline Do you broaden your knowledge of proper nutrition? & 0.179 & $0.105^{*}$ \\
\hline Do you use dietary supplements advertised in the media? & -0.263 & $0.123^{* *}$ \\
\hline sex_female & 0.058 & 0.083 \\
\hline age_25_34 & -0.119 & 0.118 \\
\hline age_35_44 & -0.084 & 0.131 \\
\hline age_45_54 & 0.012 & 0.137 \\
\hline age_55_59 & 0.171 & 0.140 \\
\hline age_60_64 & 0.270 & $0.152^{*}$ \\
\hline age_65_or_above & -0.083 & 0.143 \\
\hline primary education & -0.552 & 0.483 \\
\hline junior high school education & -0.605 & $0.285^{* *}$ \\
\hline secondary education & 0.103 & 0.133 \\
\hline higher education & 0.178 & 0.135 \\
\hline very poor income situation & 0.253 & 0.407 \\
\hline bad income situation & 0.025 & 0.434 \\
\hline good income situation & 0.115 & 0.088 \\
\hline very good income situation & 0.031 & 0.140 \\
\hline place of residence_city & -0.002 & 0.086 \\
\hline cons & 1.869 & $0.299 * * *$ \\
\hline $\mathrm{R}^{2}$ & 0.25 & \\
\hline $\mathrm{N}$ & 637 & \\
\hline
\end{tabular}

Column $b$ provides estimates of regression coefficients; column std (b) contains the average parameter estimation errors calculated using a formula resistant to random component heteroscedasticity; statistically significant estimates are marked with stars:

${ }^{*} p<0.1$; ** $p<0.05$; *** $p<0.01$

Source: own study based on the results of primary research

It should be noted that results are positively aligned with research conducted by Krawecka and Gębarowski (2015), who indicate the benefits of purchasing food products supplied by a short food supply chain for Polish consumers. The values and behaviour of ethnocentric consumers are reflected in the perceived benefits of short supply chains. They point at the high quality of products, their greater health and nutritional value and the favourable relation between the price of purchased products and their quality. Moreover, they emphasise greater certainty and safety regarding the 
origin of the products, the possibility of direct contact with farmers and producers, the greater availability of niche products, environmental protection (shorter transport), as well as the economic aspects of purchases and their positive impact on the local economy. Taking into account the fact that thanks to numerous social campaigns and consumer education, the level of nutritional awareness is increasing in Poland, the abovementioned factors concern an increasing number of consumers. Therefore, in response to changes in consumer attitudes, looking for fresh, authentic food, without chemicals, directly from the farmer, food producers must act together, creating short supply chains. It should be noted that Poland has a high potential for the development of short supply chains, which is related to the fact that small farms predominate in Poland. According to the GUS research (2016), the largest number of farms has an area of up to 10 hectares. In the category of 1-10 hectares of agricultural land there were more than 1.04 million farms in Poland, or $73.3 \%$ of farms. They occupied $28.2 \%$ of farmland. This means that Poland is a powerhouse in terms of small farms. Within the European Union, only Romania exceeds this percentage. It is worth noting, however, that in Poland, the perception of the short supply chain as an important element of the food economy is a relatively new phenomenon. It should be remembered that, until recently (2016), in Poland farmers did not have the legal capacity to process and sell food produced in their farms. The short supply chain was only prioritised in Government programmes in 2017.

\section{Conclusions}

The main purpose of this paper was to identify and characterise the phenomenon of ethnocentrism in the food behaviour of Polish consumers, the factors shaping it and its link with the short food supply chain development in the Polish food market. Across the studies covered by this paper, it was found that ethnocentrism is clearly visible in the food behaviours of Poles and it might have significant influence on the development of short supply chains, which confirms the hypothesis of work.

The development of short food supply chains is of growing interest to public institutions at local, national and European level, as there is growing recognition that fundamental changes in the way food systems are organised have to take place because of the negative environmental impact of some practices and, as direct research has shown, consumer preferences. The most important factor in terms of interest in SFSC systems is not so much due to policy, but due to changes on the consumer side. In recent years, the quality and origin of food increasingly matters to consumers.

It should be noted that SFSCs, focusing on consumer needs and sustainable production methods, can be crucial for the future development of Polish and European agriculture. To that end, the development of new forms of agricultural market organisation is required that takes into account small farms and producers in the food supply chains. Small farms should be treated as providing an opportunity for rural development, thus prompting a reform of the food economy. Support for the collective direct sales of small farms and producers must be provided by the Ministry of Agriculture and Rural Development. Enabling the sale of food produced in small farms may contribute to the maintenance of jobs in traditional agriculture, while at the same time providing consumers with access to high-quality Polish food. 


\section{References}

Annunziata, A., \& Scarpato, D. (2014). Factors affecting consumer attitudes towards food products with sustainable attributes. Agricultural Economics, 60(8), 353-363.

Autio, M., Collins, R., Wahlen, S., \& Anttila, M. (2013). Consuming nostalgia? The appreciation of authenticity in local food production. International Journal of Consumer Studies, 37(5), 564-568.

Balabanis, G., \&Diamantopoulos, A. (2004). Domestic country bias, country-of-origin effects, and consumer ethnocentrism: a multidimensional unfolding approach. Journal of the Academy of Marketing Science, 32(1), 80-95.

Canfora, I. (2016). Is the short food supply chain an efficient solution for sustainability in food market. Agriculture and agricultural science procedia, 8(1), 402-407.

Chryssochoidis, G., Krystallis, A., \&Perreas, P., (2007). Ethnocentric beliefs and country-of-origin (COO) effect: Impact of country, product and product attributes on Greek consumers'evaluation of food products, European Journal of Marketing, Vol. 41 Issue: 11/12, 1518-1544.

Chudy, S., \& Gieraltowska, U. (2013). Produkty tradycyjne i regionalne z perspektywy szczecińskich studentów. Journal of Agribusiness and Rural Development, 1 (27), 45-52.

Coley, D., Howard, M., \& Winter, M. (2011). Food miles: time for a re-think?. British Food Journal, No. 113 (7), 919-934.

D'amico, M., Di Vita, G., Chinnici, G., Pappalardo, G., \& Pecorino, B. (2014). Short food supply chain and locally produced wines: factors affecting consumer behavior. Italian Journal of Food Science, 26(3), 329-334

EIP-AGRI Focus Group, Innovative Short Food Supply Chain managemen. 2015. Aviable at: https://ec.europa.eu/eip/agriculture/sites/agri-eip/files/eip-

agri_fg_innovative_food_supply_chain_management_final_report_2015_en.pdf 13/03/2020]. SEEP:

Galli F., Brunori G., eds. (2013), Short Food Supply Chains As Drivers of Sustainable Development. Evidence Document, Document developed in the framework of the FP7 project FOODLINKS (GA No. 265287). Laboratorio di studi rurali Sismondi, ISBN 978-88-90896-01-9.

Gradziuk, B. (2015). Postawy i zachowania producentów oraz nabywców względem żywności lokalnej [ang. Attitudes and behaviours of producers and consumers towards local food]. Roczniki Nankowe Stowarzyszenia Ekonomistów Rolnictwa i Agrobiznesu, 17(3), 96-102.

GUS (2016), Charakterystyka Gospodarstw Rolnych w 2016 r. [ang. The characteristic of Polish farms in 2016). Aviable at: <https://stat.gov.pl/obszary-tematyczne/rolnictwo-lesnictwo/rolnictwo/charakterystykagospodarstw-rolnych-w-2016-r-,5,5.html> [Accessed: 9/03/2020]

Karner, S. (red.). (2010). Local Food Systems in Europe. Case studies from five countries and what they imply for policy and practice. Graz: IFZ. Aviable at: < http://www.genewatch.org/uploads/f03c6d66a9b354535738483c1c3d49e4/FAAN_Booklet_PRI NT.pdf> [Accessed: 13/03/2020]

Kavak, B., \& Gumusluoglu, L. (2007). Segmenting food markets-the role of ethnocentrism and lifestyle in understanding purchasing intentions. International Journal of Market Research, 49(1), 71-94.

Marsden, T., Banks, J., \& Bristow, G. (2000). Food supply chain approaches: exploring their role in rural development. Sociologia ruralis, 40(4), 424-438.

Opinion of the Committee of the Regions on 'Local food systems' (outlook opinion) Aviable at $<$ https://eur-lex.europa.eu/legal-content/EN/TXT/?uri=CELEX\%3A52010AR0341> [Access: $4 / 03 / 2020]$

Pretty, J. N., Ball, A. S., Lang, T., \& Morison, J. I. (2005). Farm costs and food miles: An assessment of the full cost of the UK weekly food basket. Food policy, 30(1), 1-19.

Renting, H., Marsden, T. K., \& Banks, J. (2003). Understanding alternative food networks: exploring the role of short food supply chains in rural development. Environment and planning A, 35(3), 393-411.

Sajdakowska, M., (2003). Consumer ethnocentrism - a factor influencing consumer purchasing decisions on the food market, Technologia Alimentaria 2(1) 2003, 177-184.

Shankarmahesh, M. N., (2006). Consumer ethnocentrism: an integrative review of its antecedents and consequences. International Marketing Review, 23(2), 146-172. 
Sharma, S., Shimp, T. A., \& Shin, J. (1994). Consumer ethnocentrism: A test of antecedents and moderators. Journal of the Academy of Marketing Science, 23(1), 26-37.

Shimp, T. A., \&Sharma, S., (1987). Consumer ethnocentrism: construction and validation of the CETSCALE. Journal of Marketing Research, 24(3), 280-289.

Szromnik, A., \&Wolanin-Jarosz, E., (2014). Etnocentryzm konsumencki na zglobalizowanym rynku czynniki i procesy kształtowania cz.2 [ang. Consumer ethnocentrism on a globalized market factors and processes of shaping (part 2)], Marketing i Rynek, 5/2014, 2-13.

Taylor, D. M., \&Jaggi, V., (1974). Ethnocentrism and causal attribution in a South Indian context. Journal of cross-cultural Psychology, 5(2), 162-171.

Tundys, B. (2015). Krótki łańcuch dostaw produktów spożywczych (SFSC)-ujęcie teoretyczne i praktyczne (Short food supply chain (SFSC) - theoretical and practical approach). Studia Ekonomiczne, 249, 94 110.

Watson, J., \&Wright, K. (2000). Consumer ethnocentrism and attitudes toward domestic and foreign products. European journal of Marketing, 34(9/10), 1149-1166.

Włodarczyk, K., (2015). Globalizacja a patriotyzm ekonomiczny polskich konsumentów [ang. Globalization and economic patriotism of Polish consumers], Studia Ekonomiczne. Zeszyty Naukowe Uniwersytetu Ekonomicznego w Katowicach, 214, 69.

Zakowska-Biemans, S. (2012). Zywność tradycyjna z perpektywy konsumentów [ang. Traditional food from a consumer perspective]. Zywność. Nauka. Technolologia Jakość, 3(82), 5-18.

Zięba, K., \&Ertmański, S. (2006). Rola etnocentryzmu konsumenckiego oraz kraju pochodzenia produktu w podejmowaniu decyzji zakupowych konsumentów [ang.The role of consumer ethnocentrism and the product's country of origin in making consumer purchasing decisions], Zessyty Naukowe Uniwersytetu Szczecinskiego, 438, 98-111. 